\title{
弱毒ウイルス利用による カンキツトリステザウイルスの防除
}

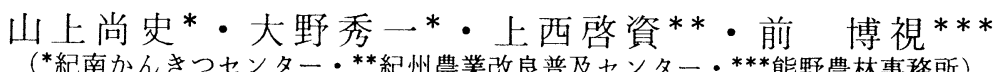

(*紀南かんきつセンター・**紀州農業改良普及センター・***熊野農林事務所)

中晚生カンキツ類は, 強毒系統のカンキットリステ ザウイルス（以下CTVといら）に侵されると，樹勢 の低下，果実の小玉化等の症状を生じる。県内に導入 されている中晚生カンキッ類においてもCTVの影響 による生産性の低下が見られている。しかし，弱毒系 統のウイルスを苗木に接種し，その干渉効果により強 毒系統の感染を軽隇することがでさると報告されてい る。そこで，弱毒ウイルス接種による防除の実用性に ついて検討した。

\section{材料及び方法}

農林水産省果樹試験場與津支場より分譲を受けた弱 毒系統（第 1 表）からキコク台による苗木を宮内伊予 柑，森田ネーブル，セミノ一ルで育成，1988年 4 月に 場内注場へ 1 年生苗木を植栽した。対照となる強毒采 統は，場内の汪場から選抜，苗木を育成し，1987年 4 月に 2 年生の苗木を植栽した。供試樹は 1 系統当たり $1 \sim 3$ 樹とし, 調査は樹容積の測定を植栽時と各年次 の生育停止期に 2 反復で行った。収量, 果実品質の調 查は，宮内伊予柑，森田ネーブルで 1 月に，セミノ一 ルで 4 月に行った。ステムピッティングの調査は宮内 伊予柑，セミノールは1990年 1 月に，森田ネーブルは 1991年 1 月に行った。かいよ5性虎斑病の調查は宮内 伊予柑で行った。

\section{第 1 表 供試弱毒系統}

\begin{tabular}{l|l}
\hline \hline & \multicolumn{1}{|c}{ 弱 毒 系 統 } \\
\hline 宮内伊予柑 & $\mathrm{M}-10, \mathrm{M}-12, \mathrm{M}-23 \mathrm{~A}, \mathrm{M}-27$ \\
森田ネーブル & $\mathrm{M}-10, \mathrm{M}-15 \mathrm{~A}, \mathrm{M}-16, \mathrm{M}-23$, \\
& $145,1597,1605,2120$ \\
セミノール & $\mathrm{M}-10, \mathrm{M}-16 \mathrm{~A}, 1605$ \\
\hline
\end{tabular}

\section{結果及び考察}

定植 7 年後, 8 年生の樹体の調査では, 宮内伊予柑 の $\mathrm{M}-23 \mathrm{~A}$ 接種区, 森田ネーブルの $\mathrm{M}-15 \mathrm{~A}$ 接種区, セミノールの $\mathrm{M}-10$ 接種区で強毒接種区と比較して大 きな樹容積を示した（第1困）。困に示していない区
では，宮内伊予柑の $\mathrm{M}-27$ 接種区，森田ネーブルのM -10接種区で強毒接種区より生育が劣ったが，この 2 品種の他の弱毒接種区では強毒接種区より良好な生育 を示した。セミノールではすべての弱毒接種区が強毒 接種区と比較して良好な生育を示した。

1 樹あたりの収量は，宮内伊予柑の $\mathrm{M}-23 \mathrm{~A}$ 接種区， 森田ネーブルの $\mathrm{M}-15 \mathrm{~A}$ 接種区, セミノールの $\mathrm{M}-10$ 接種区で強毒接種区と比較して高かった（第 2 図）。 図に示していない区では，宮内伊予柑の $M-10 ， M-$ 12接種区で強毒接種区と比較して低い収量を示したが， それ以外は高い值を示した。森田ネーブル，セミノ一 ルではすべての弱毒接種区で強毒接種区より高い収量 を示した。

1 果平均重は, 宮内伊予柑で第 3 図に示したM-23 A 接種区だけでなく，他の弱毒接種区でも強毒接種区 と明瞭な差は見られなかった。森田ネーブルのM-15 $\mathrm{A}$ 接種区, セミノールのM-10接種区では強毒接種区 よりも高い值を示した（第3図）。図に示さなかった 区では，森田ネーブルで $\mathrm{M}-10$ 接種区が強毒接種区と 比較して低かったが，他の弱毒接種区は強毒接種区よ りも高かった。セミノールはすべての弱毒接種区が強 毒接種区よりも高かった。

宮内伊予柑はかいよう性虎斑病の調査も行ったが, 第 4 図に示した $M-23 A$ 接種区や，その他の弱毒接種 区で，強毒接種区より低い発病度に抑えられた。

果実品質については，宮内伊予柑，森田ネーブル， セミノ一ルのいずれも, 弱毒, 強毒接種間での差は見 られなかった。

以上より弱毒ウイルス接種によるCTV発病抑制効 果は，1部を除いた浪济すべての弱毒系統で見られた。 とくに宮内伊予柑では $M-23 \mathrm{~A}$ ，森田ネーブルでは $M$ $-15 \mathrm{~A}$ ，セミノールでは $\mathrm{M}-10$ で高い接種効果が期待 できる。

しかし，果実の収穫ができるようになって 5 年しか 経過しておらず，弱毒系統による長期の干涉効果につ

Takashi Yamakami*, Hidekazu Ohno*, Hiroshi Uenishi* ${ }^{* *}$ and Hiroshi Mae ${ }^{* * *}$ ( ${ }^{*}$ Mie Agr. Res. Ctr. Dept. Kinan Citrus Fruits, ${ }^{* *}$ Kishyu Agr. Ext. Office, ${ }^{* * *}$ Kumano Agri. Adm. Office) : Protection against severe citrus tristeza virus by use of mild strain of citrus tristeza virus. 1996年 1 月31日受理 
いては，まだ不明であるので，今後も調査を続ける必

要がある。

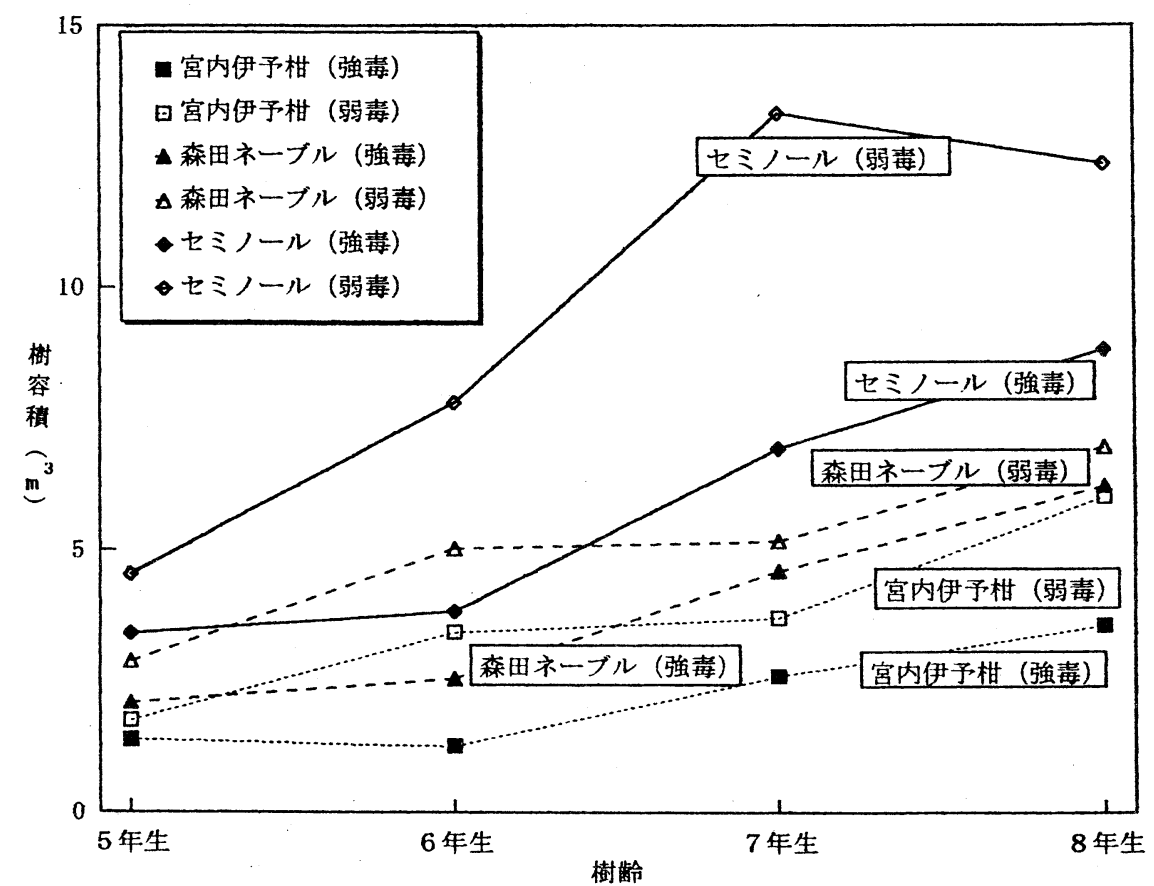

第 1 図 各品種の弱毒接種と樹容皘の推移（弱毒系統は，宮内伊予柑でM-23A接種区，森田ネーブルでMー15A接 種区,セミノールでMー10接種区を示した。)

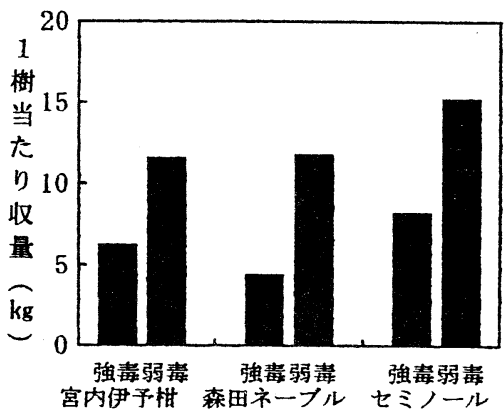

第 2 図 各品種への弱毒接種が収量に与える効果（グ ラフは 5 年生から 8 年生の平均)

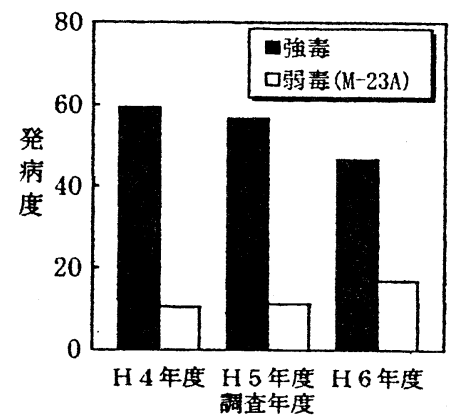

第4図 宮内伊予柑への弱毒接種が，かいよう性虎斑 病の発病に及ぼす効果

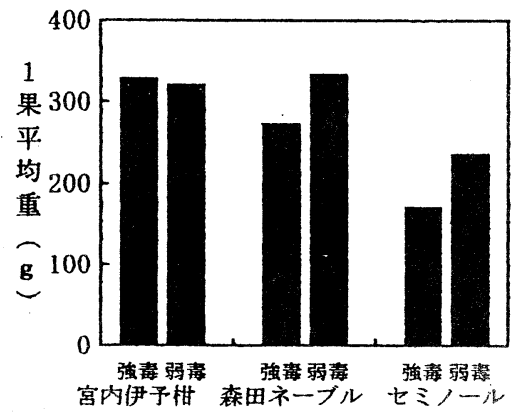

第 3 図各品種への弱毒接種が果実肥大に与える効果 （グラフはH 3 年度からH 6 年度の平均）

注）第 2 図〜第 4 図の弱毒系統は宮内伊予柑がM-23 $\mathrm{A}$ 接種区, 森田ネーブルが $\mathrm{M}-15 \mathrm{~A}$ 接種区, 七ミ ノールが $\mathrm{M}$-10接種区のデータを示した。 